\title{
NOMENCLATURAL CHANGES IN SCHIZACHYRIUM (POACEAE)
}

\author{
StePhan L. Hatch
}

\begin{abstract}
Hatch, Stephan L. (Department of Animal and Range Sciences, New Mexico State University, Las Cruces, NM 88003). Nomenclatural changes in Schizachyrium (Poaceae). Brittonia 30: 496. 1978.-Two morphological variants of Schizachyrium hirtiflorum are reduced to varietal rank under S. sanguineum. Schizachyrium semiberbe is included as a synonym of the typical variety of $S$. sanguineum.
\end{abstract}

Agnes Chase, in her 1951 revision of Hitchcock's Manual of the Grasses of the United States concurred with Hitchcock's opinion that the genus Andropogon contained several sections, including Schizachyrium. In 1967 Gould (Brittonia 19: 70-76) transferred the United States species of Schizachyrium and Bothriochloa out of the genus Andropogon. These changes now have been quite generally accepted in this country.

In a recent study of selected American species of Schizachyrium [Hatch, S. L., A biosystematic study of the Schizachyrium cirratum-S. sanguineum complex (Poaceae), Ph.D. dissertation, Texas A\&M University, College Station, 1975], two new name combinations and the reduction of one commonly recognized species to synonymy were proposed. The species S. semiberbe Nees [Andropogon semiberbis (Nees) Kunth] of southeastern United States, Mexico, Cuba, Ecuador, Peru and Brazil was compared morphologically, cytologically and anatomically with S. sanguineum (Retz.) Alston of Asia and Africa, and it was concluded that S. semiberbe should be treated as a synonym of $S$. sanguineum var. sanguineum.

The following nomenclatural changes in Schizachyrium will make these names available for use in the systematic treatment entitled, The Grasses of Baja California, now in preparation by Frank W. Gould.

Schizachyrium sanguineum (Retz.) Alston var. brevipedicellatum (Beal) Hatch, comb. nov.

Andropogon hirtiflorus (Nees) Kunth var. brevipedicellatus Beal, Grasses N. Amer. 2: 44. 1896. TyPe: MEXICO. Chinuahua: Pringle 382 (US).

Schizachyrium sanguineum (Retz.) Alston var. oligostachyum (Chapman) Hatch, comb. nov.

Andropogon oligostachyum Chapman, FI. S. U.S. 581. 1860. Andropogon hirtiflorus (Nees) Kunth var. oligostachyus (Chapman) Hackel in A. DC. \& C. DC. Monogr. Phanerog. 6: 372. 1889. Type: UNITED STATES. Florida (Middle): Chapman s.n.

Brittonia 30: 496. October-December, 1978. 